ISTIGHNA, Vol. 1, No 2, Juli 2018 P-ISSN 1979-2824

Homepage: http://e-journal.stit-islamic-village.ac.id/index.php/istighna

Rosita

Pengaruh Refleks Bayi Sebagai Pertahanan Awal Kehidupannya

\title{
PENGARUH REFLEKS BAYI SEBAGAI PERTAHANAN AWAL KEHIDUPANNYA
}

\author{
Rosita \\ (rositajkt1981@gmail.com) \\ Dosen Sekolah Tinggi Ilmu Tarbiyah (STIT) Islamic Village Tangerang
}

\begin{abstract}
Abstrak: Penelitian ini dilakukan dengan latar belakang kurangnya pemahaman orang tua tentang reflaks - refleks yang ada pada anaknya (baca; bayi), sehingga muncul paradigma yang tidak sesuai dengan perkembangan bayi. Selain itu kurangnya pemamahan tersebut membuat fakta menjadi pemahaman mitologi yang tidak sesuai dengan fakta dan teori yang sepatutnya diberikan dan distimulasi untuk pertahanan kehidupan bayi selanjutnya. Dengan demikian tujuan penelitian ini adalah untuk memberikan pemahaman tentang pengaruh refleks bayi sebagai proses awal pertahanan kehidupannya. Penelitian ini dilakukan pada beberapa orang bayi. Dengan waktu pelaksanaan awal perkembangan bayi (0-6 bulan usia bayi). Penelitian ini menggunakan rancangan penelitian kualitatif. Analisis data menggunakan analisis kualitatif. Data diperoleh dengan berpedoman pada instrumen penelitian yang mengacu pada aspek refleks bayi. Dengan demikian penelitian ini diharapkan. memberikan wacana baru yang positif dan memiliki tujuan untuk memberikan pemahaman sebenarnya yang terjadi di sekitar kita
\end{abstract}

Katakunci: Refleks bayi, Penelitian kualitatif.

\section{A. Pendahuluan}

Pendidikan anak dini usia merupakan suatu proses pembinaan dan tumbuh kembang anak semenjak bayi keluar dari rahim ibunya. Pembinaan dan pendidikan dilakukan secara menyeluruh baik dalam aspek fisik maupun non fisik, dengan memberikan rangsangan bagi perkembangan jasmani, rohani (moral dan spiritual), motorik, akal fikir, emosional dan sosial yang dilakukan secara tepat dan benar agar anak dapat tumbuh dan berkembang secara optimal, seprti yang tertuang dalam hasil konferensi Genewa tahun 1979.

Pendidikan paling dasar untuk anak usia dini terletak sejak usia lahir, pada usia ini merupakan pondasi dari kematangan untuk aspek pertumbuhan dan perkembangan anak untuk usia yang selanjutnya. Apabila pelaksanaan pendidikan pada anak sejak usia lahir dapat berjalan dengan baik maka proses pendidikan di usia selanjutnya juga akan berjalan dengan baik bahkan akan berkembang dengan optimal. 
ISTIGHNA, Vol. 1, No 2, Juli 2018 P-ISSN 1979-2824

Homepage: http://e-journal.stit-islamic-village.ac.id/index.php/istighna

Rosita

Pengaruh Refleks Bayi Sebagai Pertahanan Awal Kehidupannya

Pada masa anak usia lahir dari kemampuan otak anak sangat berbeda sekali dengan otak orang dewasa sehingga dapat diartikan bahwa seorang anak akan sangat terbuka dalam menerima berbagai macam pembelajaran dan berbagai macam pengetahuan baik yang bersifat positif maupun negatif.

Selain perkembangan otak bayi yang jumlahnya sangat pesat pada saat itu ada pula faktor yang berpengaruh bagi kelangsungan hidup seorang bayi, yaitu refleks-refleks pada bayi. Sejak lahir, tiap bayi punya refleks-refleks yang berfungsi sebagai proses awal interaksi ke dunia dan pertahanan diri. Refleks perlu dirangsang agar kecerdasan dan kematangan dan kemampuan sosialnya berkembang baik.

Menurut Psikolog Fakultas Psikologi Universitas Indonesia, Dra. Retno Pudjiati Azhar menerangkan bahwa refleks pada bayi merupakan gerakan primitif yang tak terkontrol atau gerakan involuntary. "Gerakan ini tak diajarkan, tapi ada dalam diri bayi secara biologis, bahkan mungkin sejak di kandungan,". Jadi, sifatnya bawaan. ${ }^{32}$ Hal tersebut merupakan bagian pertahanan diri dari sesuatu hal yang bisa membahayakan diri bayi.

Namun, refleks yang muncul pada bayi terkadang ditanggapi oleh masyarakat awam sebagai sesuatu yang tidak lazim. Contohnya: Bayi yang baru lahir sedang tidur nyenyak. Ibu dan bapak pasti akan mendapati atau tak jarang si kecil tiba-tiba bergerak seperti orang kaget tapi tak terbangun. Sehingga, tak sedikit orang tua yang takut, nanti bayinya akan kena penyakit jantung lantaran kerap terkaget-kaget seperti itu. Padahal, tiap bayi baru lahir pasti akan menunjukkan gerakan seperti itu, yang disebut refleks kaget atau refleks Moro. Berdasarkan dari fenomena tersebut, maka penelitian ini diajukan.

\section{B. Gerak Refleks Bayi}

Refleks dalam KBBI adalah gerakan otomatis dan tidak dirancang terhadap rangsangan dari luar yang diberikan suatu organ atau bagian tubuh yg terkena. ${ }^{33}$ Dengan demikian refleks bisa diartikan sebagai gerakan yang tanpa disadari dilakukan karena suatu kausalitas. Dan seorang bayi memiliki gerak refleks

32 http://www.tabloidnova.com/Nova/Keluarga/Anak/Mengenal-Lebih-Jauh-Refleks-PadaBayi

${ }^{33}$ https://artikbbi.com/refleks/ 
ISTIGHNA, Vol. 1, No 2, Juli 2018 P-ISSN 1979-2824

Homepage: http://e-journal.stit-islamic-village.ac.id/index.php/istighna

Rosita

Pengaruh Refleks Bayi Sebagai Pertahanan Awal Kehidupannya

tersebut sebagai proses adaptasi kondisi tersebut sesuai dengan teori belajar Piaget bahwa pada proses belajar anak akan memerlukan adaptasi, adaptasi memerlukan keseimbangan antara dua proses yang saling menunjang yaitu asimilasi dan akomodasi. Asimilasi dan akomodasi terjadi sama-sama saling mengisi pada setiap individu yang menyesuaikan diri dengan lingkungannya. Dan refleks ini bagian dari awal belajar bayi mengenal lingkungannya.

Perkembangan fisik bayi dalam dua tahun pertama kehidupan sangatlah ekstensif. Pada saat lahir, bayi memiliki kepala yang sangat besar bila dibandingkan dengan bagian tubuh lain (1:3).

Refleks pada bayi memiliki beberapa nama dan fungsi yang berbeda pula, dari kepala sampai kaki. Pertama, refleks mencari (rooting-reflex), refleks menghisap (sucking-reflex), refleks peluk (moro-reflex), refleks menggenggam (grasping-reflex), dan refleks genggam kaki (babinski-reflex). Refleks-refleks tersebut sangat penting, karena merupakan mekanisme pertahanan hidupnya. Biasanya refleks-refleks tersebut akan menghilang ketika bayi berusia antara 3-4 bulan. $^{34}$

Pendapat serupa juga dijelaskan oleh Monks bahwa Anak yang baru dilahirkan memiliki sejumlah refleks. Refleks ini merupakan dasar bagi bayi untuk mengadakan reaksi dan tindakan yang aktif. Dalam buku ini juga dikemukakan bahwa beberapa refleks ini akan menghilang dalam waktu tertentu dan disebut refleks anak menusu atau refleks bayi. Ada pula yang tidak menghilang atau disebut refleks permanen. Termasuk yang terakhir ini adalah refleks Achilles (kontraksi urat-urat daging bila urat Achilles dipukul), refleks urat lutut atau refleks Patellair (kontraksi urat-urat daging bila ada pukulan pada urat dibawah lutut) dan refleks pupil (mengecilnya pupil bila ada sinar masuk.

Adapun yang termasuk refleks anak sementara adalah : ${ }^{35}$

a. Refleks Moro : dalam gerak refleks ini akan mengembangkan tangan ke samping lebar-lebar, melebarkan jari-jari atau mengembalikan tangannya

\footnotetext{
${ }^{34}$ Santrock, John W. Life Span Development. Jilid 1 (Alih Bahasa: J. Damanik san A. Chusairi). Jakarta: Erlangga, 2002.

${ }^{35}$ F.J. Monks A.M.P Knoers, Ontwikkelings Psychology, terj. Siti Rahayu Haditono, (Yogyakarta: Gadjah Mada University Press, 1998), cet. 11. hlm.84-85
} 
ISTIGHNA, Vol. 1, No 2, Juli 2018 P-ISSN 1979-2824

Homepage: http://e-journal.stit-islamic-village.ac.id/index.php/istighna

Rosita

Pengaruh Refleks Bayi Sebagai Pertahanan Awal Kehidupannya

dengan tarikan cepat seakan ingin memeluk seseorang (dari itu direfleks ini juga disebut refleks peluk). Refleks ini bisa ditimbulkan dengan memukul bantal dikedua samping kepala anak atau dengan menepuknepuk tangan, artinya refleks ini timbul karena anak terkejut. Biasanya akan mulai menghilang sekitar 4 bulan dan sesudah 6 bulan hanya dapat ditimbulkan dengan susah payah.

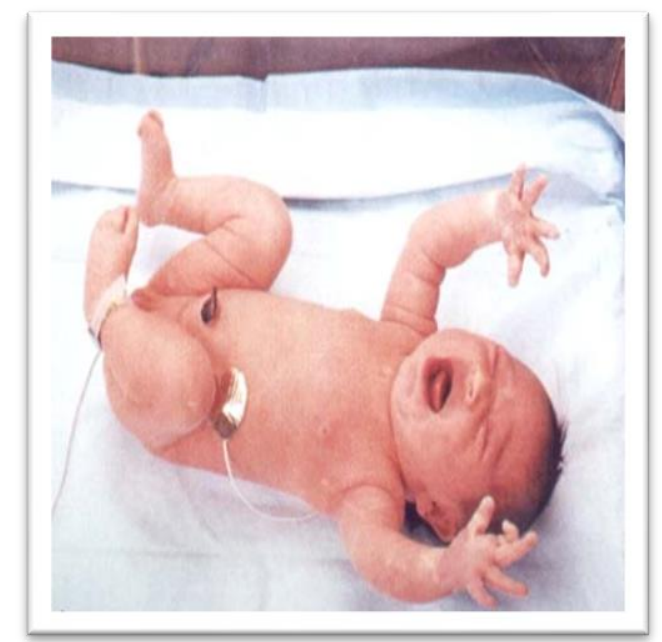

b. Refleks mencium-cium atau "rooting-refleks": Refleks ini ditimbulkan oleh stimulasi taktil pada pipi atau daerah mulut. Anak mereaksi dengan memutar-mutar kepalanya seakan-akan mencari putting susu. Refleks ini ada dalam hubungan langsung dengan refleks selanjutnya.

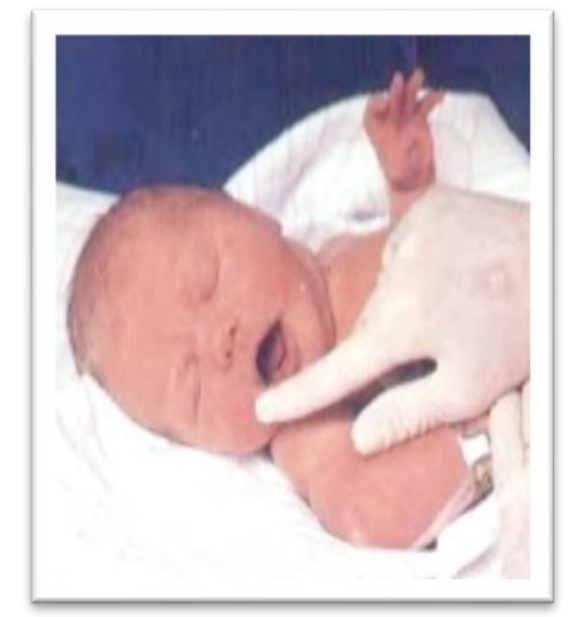

c. Refleks Hisap : Refleks mencium-cium dan refleks hisap biasanya timbul bersama-sama dengan merangsang pipi. refleks-refleks ini mempunyai fungsi eksploratif yang menenangkan. Merupakan hal yang terkenal 
ISTIGHNA, Vol. 1, No 2, Juli 2018 P-ISSN 1979-2824

Homepage: http://e-journal.stit-islamic-village.ac.id/index.php/istighna

Rosita

Pengaruh Refleks Bayi Sebagai Pertahanan Awal Kehidupannya

bahwa bayi pada bulan-bulan pertama ingin menyelidiki keliling melalui daerah mulut.dari itu kedua refleks ini disebut refleks oral. Kedua refleks ini akan menghilang sekitar 6 bulan.

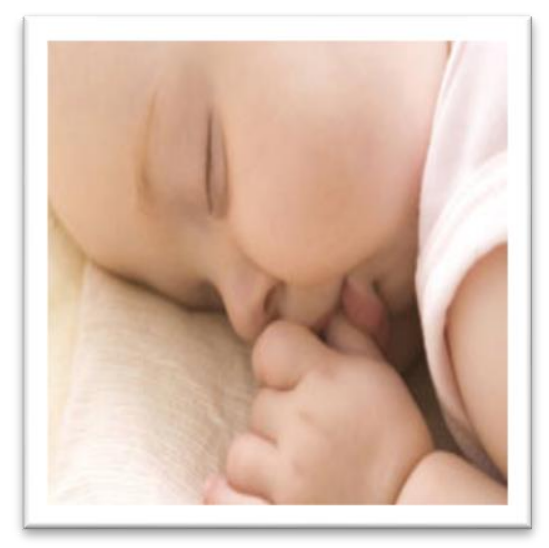

d. Refleks Genggam atau Refleks Darwin : bila kita membuat rangsang dengan menggoreskan jari melalui bagian dalam lengan anak kearah tangan, tangan akan membuka bila rangasang hamper sampai pada telapak tangan. Bila jari diletakkan pada telapak tangan anak akan menutup telapak tangannya tadi.

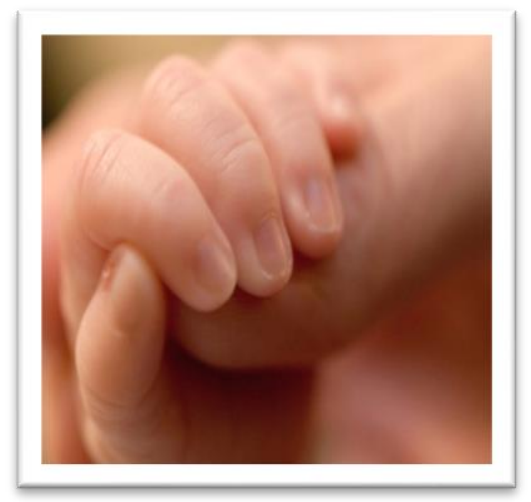

e. Refleks Babinski : adalah semacam refleks genggam kaki. Bila ada rangsang pada telapak kaki, ibu jari kaki akan bergerak ke atas dan jarijari lain membuka. Kedua refleks ini akan menghilang pada sekitar 6 bulan. 
ISTIGHNA, Vol. 1, No 2, Juli 2018 P-ISSN 1979-2824

Homepage: http://e-journal.stit-islamic-village.ac.id/index.php/istighna

Rosita

Pengaruh Refleks Bayi Sebagai Pertahanan Awal Kehidupannya

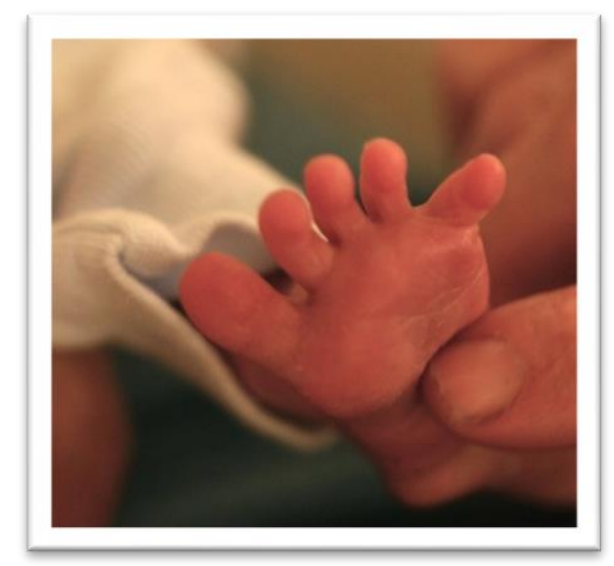

f. Ada pula salah satu refleks yaitu Refleks leher (Tonic Neck Reflex/

TNR) Yaitu: Akan terjadi peningkatan kekuatan otot (tonus) pada lengan dan tungkai sisi ketika bayi Anda menoleh ke salah satu sisi. ${ }^{36}$

\section{Fungsi Gerak Refleks Bayi}

Kemampuan motorik bayi yang baru lahir adalah gerakan-gerakan motorik yang didesain untuk pertahanan diri. ${ }^{37}$ Dan gerak refleks merupakan respon otomatis terhadap stimulus tertentu. Beberapa gerak refleks yang dimiliki bayi memiliki fungsi untuk bertahan hidup. Contohnya, rooting reflex, membantu bayi menemukan putting susu ibunya pada saat proses pamberian ASI. Selanjutnya, jika gerak menelan tidak terjadi secara otomatis, maka bayi tidak dapat bertahan hidup.

Selain memiliki fungsi untuk bertahan hidup, gerak refleks yang dimiliki bayi membantu pencapaian interaksi yang memuaskan antara orangtua dengan bayi. Bayi yang mencari, dan berhasil menemukan putting susu ibunya, menelan dengan mudah selama proses feeding, dan menggenggam saat tangannya disentuh akan membuat orangtua atau pengasuh memberikan respon dengan penuh perasaan dan merasa kompeten sebagai caregivers.

Bahkan, refleks bisa menjadi tools atau alat bagi ahli untuk mengindikasi ada-tidak suatu kelainan pada si bayi. Makanya, begitu bayi lahir, dokter akan mendeteksi perkembangan awalnya dengan melihat refleks-refleks. "Bila refleksnya tak muncul, bisa dikarenakan perkembangan yang lambat pada otak

\footnotetext{
${ }^{36}$ Eileen Allen, Marotz, RN., Developmental Profiles: Pre-Birth Trough Twelve. New York: Thompson Delmar Learning, 2008.
} 
ISTIGHNA, Vol. 1, No 2, Juli 2018 P-ISSN 1979-2824

Homepage: http://e-journal.stit-islamic-village.ac.id/index.php/istighna

Rosita

Pengaruh Refleks Bayi Sebagai Pertahanan Awal Kehidupannya

atau ada kerusakan otak, misal, ada trauma di kepalanya ketika lahir. Karena bagaimanapun, refleks-refleks berada dalam susunan saraf tepi otak."

\section{Keberadaan refleks-refleks pada bayi}

Secara bertahap refleks-refleks pada bayi akan menghilang seiring dengan bertambahnya usia pertumbuhan serta kematangan kemampuan pada si bayi. ${ }^{38}$

Berdasarkan ungkapan tersebut Psikolog dari Bagian Perkembangan Anak, Fakultas Psikologi UI, Dra. Retno Pudjiati Azhar pun mengungkapkan, bahwa refleks-refleks ini, pada akhirnya ada yang hilang, ada pula yang berubah jadi lebih terkontrol. Refleks yang menghilang adalah refleks Moro, biasanya di usia 5 bulan. Kemudian refleks swimming dan tonic neck yang menghilang sekitar usia 9 bulan, yaitu kala bayi sudah bisa duduk.

Sedangkan refleks-refleks yang berubah jadi terkendali adalah refleks rooting dan sucking. "Biasanya dimulai dari usia 3 bulan. Fungsinya pun jadi berkembang, yaitu kemampuan untuk makan dan minum." Demikian pula dengan refleks grasping, coughing, blinking, yawning juga tak hilang. Namun untuk refleks stepping masih menjadi perdebatan, apakah berkembang jadi kemampuan berjalan ataukah tidak.

Jika refleks-refleks yang pada saatnya harus hilang ternyata tak hilang, berarti ada sesuatu yang salah pada si kecil. "Untuk itu perlu diteliti lebih lanjut, Karena apabila hal demikian terjadi, maka perkembangannya terlambat atau ada kerusakan otak." ${ }^{39}$ Hal ini sebaiknya dikonsultasikan ke ahlinya, yaitu dokter anak.

\begin{tabular}{|c|c|c|c|}
\hline Muncul & $\begin{array}{ll}\text { - } & \text { Menjejak-jejak } \\
\text { - } & \text { Moro (refleks kaget ) } \\
\text { - } & \text { Menelan } \\
\text { - } & \text { Membuka dan menutup } \\
& \text { mata } \\
\text { - } & \text { Memegang/menggenggam }\end{array}$ & $\begin{array}{lll}\text { - Landau (Menangis dengan } \\
\text { mengeluarkan air mata) } \\
\text { (permanen seumur hidup) }\end{array}$ & $\begin{array}{l}\text {-Refleks terjun } \\
\text { (parachute) } \\
\text {-Reflex mengenggam } \\
\text {-Memegang benda } \\
\text { dengan jari }\end{array}$ \\
\hline
\end{tabular}

\footnotetext{
${ }^{38}$ Varney H. Varney's Midwifery. Third Edition. London :Jones and Bartlett Publishers International. 1997.

${ }^{39}$ (McPhilips \& Jordan-Black,2007;Herschkowitz, 2000).
} 
ISTIGHNA, Vol. 1, No 2, Juli 2018 P-ISSN 1979-2824

Homepage: http://e-journal.stit-islamic-village.ac.id/index.php/istighna

Rosita

Pengaruh Refleks Bayi Sebagai Pertahanan Awal Kehidupannya

\begin{tabular}{|c|c|c|c|c|}
\hline & $\begin{array}{l}\text { - } \text { Batuk } \\
\text { - } \text { Menjerit } \\
\text { - } \text { Menghisap } \\
\text { - } \text { Memalingkan muka bila } \\
\text { pipinya disentuh } \\
\text { - } \text { bagian tubuhnya seperti } \\
\text { bergerak ke arah sebaliknya } \\
\text { (refleks tonic neck) dengan } \\
\text { kedua tangan biasanya } \\
\text { menggenggam. } \\
\text { - } \text { gerakan berenang }\end{array}$ & & & \\
\hline Usia & Lahir & 1-4 bulan & 4-8 bulan & $8-12$ bulan \\
\hline Hilang & & $\begin{array}{l}\text { - Menggenggam (Grasp) } \\
\text { - Menghisap (menjadi voluntary) } \\
\text { - Menjejak-jejak } \\
\text { - Memalingkan muka bila pipinya } \\
\text { disentuh } \\
\text { - bagian tubuhnya seperti bergerak } \\
\text { ke arah sebaliknya (refleks tonic } \\
\text { neck) }\end{array}$ & $\begin{array}{l}\text { - Moro } \\
\text { (refleks kaget ) }\end{array}$ & $\begin{array}{l}\text { - Refleks } \\
\text { menggeng } \\
\text { gam } \\
\text { (Palmar dan } \\
\text { plantar } \\
\text { grasp) }\end{array}$ \\
\hline
\end{tabular}

Lihat table reflex bayi (Allen-Marotz:2010)

\section{E. METODOLOGI PENELITIAN}

Metode penelitian yang digunakan adalah metode kualitatif atau penelitian lapangan yang dilakukan melalui penanganan langsung dan pengamatan empiris. dengan melibatkan 5 bayi. Penelitian ini merupakan suatu pengamatan untuk melihat proses awal sosialisasi seorang bayi pada masa awal kehidupannya.

Penelitian tindakan dilakukan secara kolaboratif partisipatif dalam rangka mengubah paradigma di masyarakat. Dengan tujuan untuk :

1. Mengetahui kenyataan di dalam masyarakat tentang fenomena refleks yang ada pada setiap bayi.

2. Memahami macam-macam refleks pada bayi.

3. Mengetahui alasan adanya refleks pada bayi yang dianugerahkan oleh Yang Maha Kuasa. 
ISTIGHNA, Vol. 1, No 2, Juli 2018 P-ISSN 1979-2824

Homepage: http://e-journal.stit-islamic-village.ac.id/index.php/istighna

Rosita

Pengaruh Refleks Bayi Sebagai Pertahanan Awal Kehidupannya

4. Mengetahui efeknya jika seorang bayi tidak memiliki refleks atau refleksnya tidak hilang pada dirinya atau berdasarkan perkembangannya.

\section{F. Deskripsi Hasil Temuan}

Penelitian dilakukan pengamatan sebagai tahap awal yang dilakukan pada 6 orang bayi dengan masing-masing pertemuan. Pertemuan selanjutnya dilakukan melalui wawancara orang tua. Berdasarkan hasil observasi masing-masing bayi memiliki riwayat berkaitan refleks mereka. Saat peneliti melakukan wawancara ada beberapa penemuan yang berkaitan dan refleks bayi dengan perkembangan selanjutnya pada usia mereka, dengan tonggak pencapaian maksimal 4 tahun lebih usia sekarang.

Observasi yang dilakukan selama pelaksanaan sangat diperlukan dalam melakukan analisis data secara kualitatif. Observasi dilakukan dengan menggunakan: instrumen observasi, pedoman observasi dilakukan dengan indikator, catatan lapangan, dokumentasi dan wawancara.

\begin{tabular}{|c|c|c|c|}
\hline No. & Nama anak & Refleks yang muncul & $\begin{array}{l}\text { Efek Pada Perkembangan Bayi } \\
\text { Selanjutnya }\end{array}$ \\
\hline 1. & Faruq & $\begin{array}{l}\text { - Menjejak-jejak } \\
\text { - Moro (refleks kaget) } \\
\text { - Menelan } \\
\text { - Membuka dan menutup mata } \\
\text { - Memegang/ menggenggam } \\
\text { - Batuk } \\
\text { - Menjerit } \\
\text { - Menghisap } \\
\text { - Memalingkan muka bila pipinya } \\
\text { - disentuh } \\
\text { bagian tubuhnya seperti bergerak } \\
\text { ke arah sebaliknya (refleks tonic } \\
\text { neck) dengan kedua tangan } \\
\text { biasanya menggenggam. } \\
\text { - gerakan berenang }\end{array}$ & $\begin{array}{l}\text { Berkembang dengan optimal, } \\
\text { sehingga usia } 12 \text { bulan sudah } \\
\text { bisa jalan dan mampu } \\
\text { mengeluarkan kata yang } \\
\text { dipahami dengan notasi yang } \\
\text { jelas. }\end{array}$ \\
\hline
\end{tabular}


ISTIGHNA, Vol. 1, No 2, Juli 2018 P-ISSN 1979-2824

Homepage: http://e-journal.stit-islamic-village.ac.id/index.php/istighna

Rosita

Pengaruh Refleks Bayi Sebagai Pertahanan Awal Kehidupannya

\begin{tabular}{|c|c|c|c|}
\hline & & $\begin{array}{l}\text { - Landau (Menangis dengan } \\
\text { mengeluarkan air mata) (permanen } \\
\text { seumur hidup) } \\
\text { - } \quad \text { Refleks terjun (parachute) }\end{array}$ & \\
\hline 2. & Syahreza & $\begin{array}{l}\text { - Menjejak-jejak } \\
\text { - } \text { Moro (refleks kaget ) } \\
\text { - } \text { Menelan } \\
\text { - } \text { Membuka dan menutup mata } \\
\text { - } \text { Memegang/ menggenggam } \\
\text { - } \text { Batuk } \\
\text { - } \text { Menjerit } \\
\text { - Menghisap } \\
\text { - Memalingkan muka bila pipinya } \\
\text { - disentuh } \\
\text { bagian tubuhnya seperti bergerak } \\
\text { ke arah sebaliknya (refleks tonic } \\
\text { neck) dengan kedua tangan } \\
\text { biasanya menggenggam. } \\
\text { - gerakan berenang } \\
\text { - Landau (Menangis dengan } \\
\text { mengeluarkan air mata) (permanen } \\
\text { - } \text { seumur hidup). } \\
\text { Refleks terjun (parachute) }\end{array}$ & $\begin{array}{l}\text { Refleks mengenggam ada } \\
\text { namun refleks babinski } \\
\text { (genggam kaki) tidak maksimal } \\
\text { dan ini mempengaruhi proses } \\
\text { perkembangan motoriknya, } \\
\text { sehingga proses kemampuan } \\
\text { berjalannya agak lama (12 bulan } \\
\text { lebih/16 bulan) }\end{array}$ \\
\hline & Marsha & $\begin{array}{l}\text { - Menelan } \\
\text { - Membuka dan menutup mata } \\
\text { - Memegang/ menggenggam } \\
\text { - Batuk } \\
\text { - Menjerit } \\
\text { - Menghisap } \\
\text { - Memalingkan muka bila pipinya }\end{array}$ & $\begin{array}{l}\text { Refleks moro tidak terlihat } \\
\text { ketika bayi, dan (refleks tonic } \\
\text { neck) tidak terlihat sampai usia } \\
\text { enam bulan, sehingga sampai usia } 6 \\
\text { bulan belum dapat tengkurap. Hal } \\
\text { ini pun sangat mempengaruhi } \\
\text { motoriknya yang lain dan baru }\end{array}$ \\
\hline
\end{tabular}


ISTIGHNA, Vol. 1, No 2, Juli 2018 P-ISSN 1979-2824

Homepage: http://e-journal.stit-islamic-village.ac.id/index.php/istighna

Rosita

Pengaruh Refleks Bayi Sebagai Pertahanan Awal Kehidupannya

\begin{tabular}{|c|c|c|c|}
\hline & & $\begin{array}{l}\text { disentuh } \\
\text { - Landau (Menangis dengan } \\
\text { mengeluarkan air mata) (permanen } \\
\text { seumur hidup). } \\
\text { - } \text { Refleks terjun (parachute) }\end{array}$ & $\begin{array}{l}\text { mampu berjalan ketika usia } 4 \text { tahun } \\
\text { lebih. }\end{array}$ \\
\hline 4. & Syahira & $\begin{array}{l}\text { - } \text { Menjejak-jejak } \\
\text { - } \text { Moro (refleks kaget ) } \\
\text { - } \text { Menelan } \\
\text { - } \text { Membuka dan menutup mata } \\
\text { - } \text { Memegang/ menggenggam } \\
\text { - } \text { Batuk } \\
\text { - } \text { Menjerit } \\
\text { - Menghisap } \\
\text { - Memalingkan muka bila pipinya } \\
\text { disentuh } \\
\text { - } \text { bagian tubuhnya seperti bergerak } \\
\text { ke arah sebaliknya (refleks tonic } \\
\text { neck) dengan kedua tangan } \\
\text { biasanya menggenggam. } \\
\text { - gerakan berenang } \\
\text { - Landau (Menangis dengan } \\
\text { mengeluarkan air mata) (permanen } \\
\text { - } \text { seumur hidup). } \\
\text { Refleks terjun (parachute) }\end{array}$ & Berkembang sesuai tracknya. \\
\hline 5. & Andhara & $\begin{array}{l}\text { - Menjejak-jejak } \\
\text { - Moro (refleks kaget ) } \\
\text { - Menelan } \\
\text { - Membuka dan menutup mata } \\
\text { - Memegang/ menggenggam } \\
\text { - Batuk } \\
\text { - Menjerit }\end{array}$ & $\begin{array}{l}\text { Refleks moro jarang terlihat } \\
\text { ketika bayi dan Refleks } \\
\text { mengenggam ada namun refleks } \\
\text { babinski (genggam kaki) tidak } \\
\text { maksimal dan ini mempengaruhi } \\
\text { proses } \\
\text { motoriknya, }\end{array}$ \\
\hline
\end{tabular}


ISTIGHNA, Vol. 1, No 2, Juli 2018 P-ISSN 1979-2824

Homepage: http://e-journal.stit-islamic-village.ac.id/index.php/istighna

Rosita

Pengaruh Refleks Bayi Sebagai Pertahanan Awal Kehidupannya

\begin{tabular}{|c|c|c|c|}
\hline & & $\begin{array}{l}\text { - } \text { Menghisap } \\
\text { - Memalingkan muka bila pipinya } \\
\text { disentuh } \\
\text { - } \text { bagian tubuhnya seperti bergerak } \\
\text { ke arah sebaliknya (refleks tonic } \\
\text { neck) dengan kedua tangan } \\
\text { biasanya menggenggam. } \\
\text { - } \text { gerakan berenang } \\
\text { - Landau (Menangis dengan } \\
\text { mengeluarkan air mata) (permanen } \\
\text { seumur hidup). } \\
\text { - Refleks terjun (parachute) }\end{array}$ & $\begin{array}{l}\text { kemampuan untuk berjalannya } \\
\text { sedikit terhambat (usia } 15 \text { bulan } \\
\text { belum berjalan). }\end{array}$ \\
\hline 6. & Shaliha & $\begin{array}{l}\text { - } \text { Menjejak-jejak } \\
\text { - } \text { Moro (refleks kaget) } \\
\text { - } \text { Menelan } \\
\text { - } \text { Membuka dan menutup mata } \\
\text { - Memegang/menggenggam } \\
\text { - } \text { Batuk } \\
\text { - } \text { Menjerit } \\
\text { - Menghisap } \\
\text { - Memalingkan muka bila pipinya } \\
\text { disentuh } \\
\text { - bagian tubuhnya seperti bergerak } \\
\text { ke arah sebaliknya (refleks tonic } \\
\text { neck) dengan kedua tangan } \\
\text { biasanya menggenggam. } \\
\text { - gerakan berenang } \\
\text { - Landau (Menangis dengan } \\
\text { mengeluarkan air mata) (permanen } \\
\text { - } \text { seumur hidup). } \\
\text { Refleks terjun (parachute) }\end{array}$ & Berkembang sesuai Harapan \\
\hline
\end{tabular}


ISTIGHNA, Vol. 1, No 2, Juli 2018 P-ISSN 1979-2824

Homepage: http://e-journal.stit-islamic-village.ac.id/index.php/istighna

Rosita

Pengaruh Refleks Bayi Sebagai Pertahanan Awal Kehidupannya

Refleks mengindikasikan adanya perkembangan otak. "Sama halnya dengan refleks yang tadinya tak terkontrol lalu jadi terkontrol. Dan hal tersebut, mengindikasikan otaknya juga berkembang." Padahal, perkembangan otak sangat erat kaitannya dengan kecerdasan si bayi kelak. "Jadi, adanya gangguan perkembangan otak, pertanda kecerdasannya kelak juga akan terganggu. Dan ini terlihat pada perkembangan anak-anak yang menjadi target penelitian. Adanya refleks yang terhambat dan hal itu pun menghambat perkembangan mereka, seperti Marsha yang terhambat kemampuan motoriknya sehingga usia 4 tahun lebih baru mampu berjalan.

Bayi yang mempunyai refleks cepat terhadap suatu rangsang tertentu, lebih baik perkembangan otaknya dibanding yang refleksnya lambat. Misal, bayi yang lambat dalam refleks menggengam, biasanya motorik halusnya juga tak baik. "Hal ini tentunya akan berpengaruh pada kemampuan menulisnya kelak, yaitu jadi tak sebaik anak lain."

Selain itu, bila dilihat dari perkembangan sosialnya, refleks merupakan kemampuan sosial awal pada bayi. Misal, si ibu pegang pipi si bayi, muncul refleks si bayi seperti menoleh dan mengisap. Respon selanjutnya dari si bayi bisa tersenyum atau tertawa pada si ibu. Jadi, ada kesenangan-kesenangan pada si bayi. Ini, menurut Dra. Retno Pudjiati Azhar merupakan tahap awal dari bermain atau early infant play.

Menurut Sujiono dan Sujiono berpendapat bahwa tujuan program kegiatan bermain adalah untuk mengoptimalkan perkembangan anak secara menyeluruh berdasarkan berbagai dimensi perkembangan anak usia dini baik perkembangan sikap, pengetahuan, keterampilan dan kreativitas yang diperlukan oleh anak untuk dapat menyesuaikan diri dengan lingkungannya serta untuk pertumbuhan dan perkembangan pada tahap berikutnya. ${ }^{40}$

Terdapat beberapa cara yang bisa dilakukan untuk mambantu bayi mudah beradaptasi dengan lingkungan baru, sehingga bayi tidak mudah kaget. Cara pertama adalah dengan membiasakan bayi untuk belajar mendengar kebisingan hingga kesunyian secara bertahap. Selama ini kita melarang orang-orang untuk

${ }^{40}$ Yuliani Nurani Sujiono dkk.. Jakarta:Elex media Komputindo 2010, Hal.19 
ISTIGHNA, Vol. 1, No 2, Juli 2018 P-ISSN 1979-2824

Homepage: http://e-journal.stit-islamic-village.ac.id/index.php/istighna

Rosita

Pengaruh Refleks Bayi Sebagai Pertahanan Awal Kehidupannya

berbicara ketika bayi tertidur, karena kita berasumsi bahwa bayi akan tidur dalam kesunyian. Faktanya adalah bayi tidur setiap saat, dan jadwal dia tidur hampir sama saat bayi berada pada rahim ibu. Pada malam hari, bayi tidur dalam keadaan sunyi, karena ibu juga tidur dan semua orang juga terlelap. Namun, pada siang hari, bayi akan tertidur dalam keadaan bising, karena ibu sedang beraktivitas, bertemu dengan banyak orang, dan lain sebagainya. Terlebih, tidak banyak yang tahu bahwa rahim sangat bising, karena metabolisme tubuh ibu, aktivitas ibu, dan orang-orang disekeliling ibu. Suara ibu saja terdengar 2 kali lebih keras dari suara vacum cleaner ketika bayi berada di dalam rahim. Oleh sebab itu, biasakan bayi untuk tidur dalam keadaan seperti itu. Ketika malam hari, biarkan bayi tidur dengan keadaan tenang. Pada siang hari, putarkan musik pelan dan lembut, sehingga dia menangkap sinyal bahwa dia tidur siang.

Maka dari itu orang tua seyogyanya sering merangsang bayi, hingga refleksrefleksnya mudah dikenali. Memberikan rangsangan pada reflek-refleks bayi. Justru bisa semakin menumbuhkan keingintahuannya dan keinginannya untuk berkomunikasi dan bersosialisasi. Tentunya ini berkaitan dengan kecerdasan dan juga kemampuan sosialnya, yang akan menjadi lebih baik."

Hasil data kualitatif membuktikan bahwa adanya keterkaitan antara gerak refleks bayi terhadap perkembangan anak selanjutnya, dan pertahanan awal hidup mereka ke dunia luar. Seperti kemampuan bergerak, measukan asupan gizi dengan refleks menghisapnya. Dan hal ini terlihat pada perkembangan ananda Marsha Marsha yang terhambat kemampuan motoriknya sehingga usia 4 tahun lebih baru mampu berjalan.

Selama penelitian berlangsung, peneliti memiliki beberapa keterbatasan. Diantaranya adalah kondisi anak yang kadang tidak menentu, serta pengetahuan peneliti yang masih kurang tentang kesehatan fisik anak, sehingga ketika peneliti melakukan penelitian dan wawancara kurang puas dengan eksplorasi yang didapat. Serta keterbatasan peneliti dalam mendokumentasikan moment yang penting. 
ISTIGHNA, Vol. 1, No 2, Juli 2018 P-ISSN 1979-2824

Homepage: http://e-journal.stit-islamic-village.ac.id/index.php/istighna

Rosita

Pengaruh Refleks Bayi Sebagai Pertahanan Awal Kehidupannya

\section{G. KESIMPULAN}

Berdasarkan hasil analisis data dan pembahasan, dapat diambil kesimpulan sebagai berikut:

Hasil data kualitatif membuktikan bahwa adanya keterkaitan antara gerak refleks bayi terhadap perkembangan anak selanjutnya, dan pertahanan awal hidup mereka ke dunia luar.

Perkembangan reflleks pada anak khususnya bayi tidak memimiliki faktor mitologi yang selama ini berkembang di masyarakat. Justru sangat dikhawatirkan apabila refleks-refleks yang ada pada bayi tidak muncul sama sekali, dan hal ini perlu diantisipasi melalui assesmen pada anak/bayi tersebut khawatir mempengaruhi perkembangan motorik dan kecerdasnnya di masa yang akan datang.

\section{DAFTAR PUSTAKA}

Monks,F.J. Knoerrs, A.M.P. Haditono, Siti Rahayu. Psikologi Perkembangan. Yogyakarta:Gadjah Mada University Press. 1998.

http://www.tabloidnova.com/Nova/Keluarga/Anak/Mengenal-Lebih-Jauh-

Refleks-Pada-Bayi

Eileen Allen, Marotz, RN., Developmental Profiles: Pre-Birth Trough Twelve. New York: Thompson Delmar Learning, 2008.

Santrock, John W. Life Span Development. Jilid 1 (Alih Bahasa: J. Damanik san

A. Chusairi). Jakarta: Erlangga, 2002.

Sujiono, Yuliani Nurani dkk.. Jakarta:Elex media Komputindo 2010 